\title{
Magma residence and eruption at the Taupo Volcanic Center (Taupo Volcanic Zone, New Zealand)
}

\author{
A. S. PAMUKÇU ${ }^{1 *}$, K. A. Wright ${ }^{2}$, G. A. R. GUALDA ${ }^{3}$, \\ D. M. GRAVLEY ${ }^{4}$
}

${ }^{1}$ Geological Sci., Stanford Univ., Stanford, CA 94305 USA

(*correspondance: apamukcu@stanford.edu)

${ }^{2} 2500$ S Millbend Dr., The Woodlands, TX, 77380 USA

(kylie.wright@vanderbilt.edu)

${ }^{3}$ Earth \& Enviro. Sci., Vanderbilt Univ., Nashville, TN 37235

USA (g.gualda@vanderbilt.edu)

${ }^{4}$ Geological Sci., Univ. of Canterbury, Christchurch, 8140 NZ (darren.gravley@canterbury.ac.nz)

The Taupo Volcanic Center (TVC; Taupo Volcanic Zone [TVZ], New Zealand) has produced the two most recent silicic caldera-forming eruptions in the TVZ - the $530 \mathrm{~km}^{3}$ Oruanui supereruption and the $35 \mathrm{~km}^{3}$ Taupo large-volume eruption. Given that these magmas erupted from the same volcanic center, they offer a rare opportunity to compare the lives of large and supersized volumes of rhyolitic magma, both at the TVC and more generally. We investigate crustal storage conditions, longevity, and eruption of these magmas using a multifaceted approach combining data from crystal textures (crystal size distributions), crystal compositions (Tiin-quartz diffusion chronometry), and new and existing matrix and melt inclusion glass compositions (rhyoliteMELTS geobarometry). Oruanui glass is significantly more evolved than Taupo glass (76.7-78.3 wt. $\% \mathrm{SiO}_{2}$ and 74.575.9 wt. $\% \mathrm{SiO}_{2}$, respectively), and geobarometry results show differences in the residence depths of these magmas that are consistent with the differences in their glass silica contents (50-250 $\mathrm{MPa}$ and 280-470 $\mathrm{MPa}$, respectively). In turn, timescale analyses give notably similar, short crustal residence times for the final crystal-poor, eruptible magma bodies (decades to centuries), suggesting erupted volume is not a function of residence time. Groundmass textures are distinctly different - Oruanui samples have no groundmass crystals, while Taupo samples do. This may reflect differences in ascent duration, decompression path, and/or degree of undercooling experienced by these systems due to the differences in their storage depths. The evolution in storage depths and composition between the Oruanui and Taupo eruptions (i.e., shallow to deep, more to less evolved) is also a notably similar trend to that in a preceding central TVZ ignimbrite 'flare-up', supporting the hypothesis that the modern TVC may be flaring up. This also highlights the evolution of magma storage depths with increasing system maturity in this volcanic region. 